\title{
REVIEW
}

\section{Evidence for impaired amyloid $\beta$ clearance in Alzheimer's disease}

\author{
Kristin R Wildsmith* ${ }^{* 1}$, Monica Holley ${ }^{2}$, Julie C Savage ${ }^{2}$, Rebecca Skerrett ${ }^{2}$ and Gary E Landreth ${ }^{2}$
}

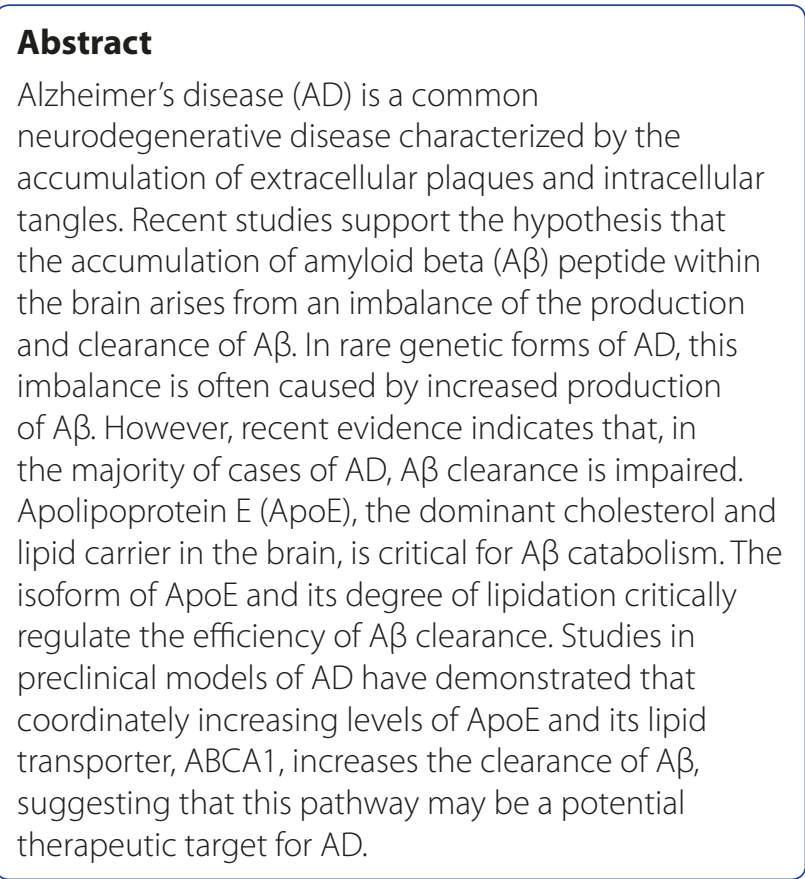

\section{Introduction}

Alzheimer's disease (AD) is the most common form of dementia. It affects nearly 27 million people worldwide, and an estimated 4.6 million new cases were diagnosed this year. Nearly $60 \%$ of those afflicted live in the Western world and the majority of these individuals are over 65 [1]. The memory loss and cognitive decline that accompany AD impart a heavy burden both emotionally and financially on patients and their families. Pathologically, $\mathrm{AD}$ is characterized by the presence of extracellular plaques composed of aggregated amyloid beta $(A \beta)$ and intraneuronal tangles composed of hyperphosphorylated tau. $A \beta$ is a peptide formed by the sequential cleavage of amyloid precursor protein (APP) by $\beta$-secretase (BACE1)

\footnotetext{
*Correspondence: wildsmith.kristin@gene.com

'Development Sciences, Genentech, Inc., 1 DNA Way, South San Francisco,

CA 94080, USA

Full list of author information is available at the end of the article
}

and $\gamma$-secretase. Evidence from genetic, biochemical, and animal model studies strongly supports the hypothesis that $A \beta$ is a causative agent in the pathogenesis of $A D$ [2]. There is growing evidence that impaired clearance of $A \beta$ (specifically of the hydrophobic form, $A \beta_{42}$ ) is responsible for the most common type of AD: sporadic or late-onset $\mathrm{AD}$ (LOAD). Age is the greatest overall risk factor for developing LOAD. However, the APOE\&4 allele is the strongest genetic risk factor for LOAD as the ApoE4 isoform is less efficient than ApoE2 or ApoE3 at promoting $A \beta$ clearance. In this review, in vivo evidence supporting the hypothesis that impaired clearance of $A \beta$ contributes to the development of AD will be covered, along with the current understanding of the influence of apolipoprotein $\mathrm{E}$ (ApoE) and cholesterol metabolism on $\mathrm{A} \beta$ clearance in the central nervous system.

\section{In vivo evidence for impaired clearance of amyloid beta in Alzheimer's disease}

In vivo microdialysis is a method used to measure levels of small diffusible proteins such as soluble $A \beta$ in the extracellular interstitial fluid (ISF) of the brain. This technique allows direct monitoring of protein levels in ISF over time in an awake, behaving animal. Microdialysis probes are small enough to measure protein levels within specific cortical or subcortical brain regions such as the hippocampus, striatum, and amygdala. When coupled with a $\gamma$-secretase inhibitor to halt production of $A \beta$, microdialysis can determine the kinetics of $A \beta$ clearance [3]. Combining microdialysis in genetic models of disease with pharmacological interventions has allowed insight into mechanisms of $A \beta$ clearance. $A \beta$ can be transported across the blood-brain barrier (BBB) by low-density lipoprotein receptor (LDLR) family members [4] or undergo proteolytic degradation intracellularly in microglia and astrocytes via neprilysin and extracellularly via insulindegrading enzyme (IDE) (for an in-depth review of $A \beta$ degrading enzymes, see [5]).

Microdialysis studies comparing young (3 months old) and old (12 to 15 months old) PDAPP mice found that the half-life of $A \beta$ within the ISF is doubled in older animals, even when $A \beta$ production was stopped by a $\gamma$ secretase inhibitor [3]. These data imply that the brain's 
ability to clear $A \beta$ diminishes with age. Hippocampal microdialysis revealed a strong correlation between the age-dependent decrease of $A \beta_{42}$ in the ISF and increase of $\mathrm{A} \beta_{42}$ in the insoluble pool in APP transgenic mice [6]. Plaque growth is dependent upon high levels of $A \beta$ in the ISF as APP/PS1 mice treated with a $\gamma$-secretase inhibitor demonstrated that even a modest decrease $(\sim 30 \%)$ of $\mathrm{A} \beta$ in ISF was enough to arrest plaque growth [7].

In vivo microdialysis studies determined that mice expressing the different human ApoE isoforms exhibit altered $\mathrm{A} \beta$ homeostasis in the ISF [8]. ApoE4 mice had higher ISF and hippocampal $A \beta$ levels, beginning as early as 3 months of age. The half-life of $A \beta$ was longest in ApoE4 mice $(E 4>$ E3 > E2). Products of APP and rate of $\mathrm{A} \beta$ synthesis did not change between genotypes, strongly pointing to a difference in the clearance, rather than the production, of $\mathrm{A} \beta$ in the ApoE2, ApoE3, and ApoE4 mice.

One challenge of working with animal models based on the genetic forms of $\mathrm{AD}$ is determining how well pathologies correlate to the sporadic form of the human disease. An encouraging example supporting the translation of mouse models to humans is from in vivo stable isotope-labeling kinetic (SILK) experiments, which allow the determination of the rates of biosynthesis and subsequent clearance of $A \beta$ peptides. These studies have demonstrated that the rates of synthesis and clearance are similar in normal subjects; thus, modest perturbations can result in accumulation of $A \beta$ in the brain [9]. An important study, by Bateman and colleagues [10], demonstrated that clearance of $A \beta$ is impaired by approximately $30 \%$ in patients with LOAD (5.6\% per hour in $\mathrm{AD}$ versus $7.6 \%$ per hour in controls). Although the mechanism is still unknown, it is likely to reflect agerelated impairment in $\mathrm{A} \beta$ clearance mechanisms which are influenced by $A P O E$ genotype.

\section{Influence of apolipoprotein E genotype on amyloid clearance}

Population studies have demonstrated that $A P O E$ genotype is the strongest risk factor for LOAD. Three common isoforms of ApoE, differing from each other at two amino acids, occur in humans: ApoE2 (cys112 and cys158), ApoE3 (cys112 and arg158), and ApoE4 (arg112 and arg158). Possession of one $\varepsilon 4$ allele imparts a threefold increase in risk for LOAD and two alleles impart a 12-fold increased risk [11], whereas the $\varepsilon 2$ allele decreases the likelihood of developing LOAD [12]. With a prevalence of about $15 \%$ in the population, the $\varepsilon 4$ allele has been estimated to account for $50 \%$ of all AD cases [13]. The $\varepsilon 4$ allele is also associated with an earlier age of onset $[14,15]$ and increased $A \beta$ deposition both in animal models of $\mathrm{AD}[8,16,17]$ and in human $\mathrm{AD}[18]$.

ApoE is the predominant apolipoprotein in the brain, where it is secreted primarily by astrocytes, but also by microglia, in high-density lipoprotein (HDL)-like particles (reviewed by $\mathrm{Bu}$ [19]). Lipidation of ApoE is mediated primarily by ATP-binding cassette A1 (ABCA1) and secondarily by ABCG1 [20,21], and the lipidation status of ApoE has been shown to regulate its $A \beta$-binding properties [22]. Direct evidence that ABCA1-mediated lipidation influences amyloid degradation has been demonstrated in multiple transgenic models of $\mathrm{AD}$. Deletion or overexpression of ABCA1 results in increased or decreased $A \beta$ deposition, respectively [23-25]. Both intracellular and extracellular degradation of $A \beta$ is also dramatically enhanced by lipidated ApoE [26]. ApoE4 is less stable [16,17] and a less effective lipid carrier under physiological conditions than ApoE3 or ApoE2 [27,28], and this probably contributes to its influence in $\mathrm{AD}$ pathogenesis. The effects of the various ApoE isoforms on $A \beta$ clearance were further investigated in targeted-replacement mice expressing human ApoE isoforms at the murine locus. $\mathrm{A} \beta$ deposition and cognitive deficits are exacerbated in $\mathrm{APP} / \mathrm{ABCA}^{+/-}$targetedreplacement mice expressing ApoE4 but not ApoE3 [29].

It has been proposed that ApoE4 modulates amyloid pathology by enhancing $A \beta$ deposition into plaques and reducing clearance of $A \beta$ from the brain [17,30-33]. One of the first pieces of evidence linking ApoE to $\mathrm{AD}$ pathology was ApoE immunoreactivity in amyloid deposits and neurofibrillary tangles [34]. It has since been shown that ApoE forms complexes with $A \beta$, with ApoE2 and E3 binding A $\beta$ more efficiently than E4 [35-37], and these complexes are thought to influence both seeding of fibrillar $A \beta$ and transport of soluble $A \beta$. It has been shown that $\mathrm{AD}$ transgenic mice lacking $A p o E$ have decreased plaque deposition and increased levels of soluble $A \beta$ in the cerebrospinal fluid and ISF $[32,38]$. Crosses between AD transgenic mice and human ApoE targeted-replacement mice exhibit $A \beta$ accumulation in an isoform-dependent manner, with greater $A \beta$ deposition observed in ApoE4-expressing mice than those expressing E2 and E3 $[8,16]$. The cause of the accumulation is most likely due to the degree to which the isoforms impact $A \beta$ clearance and deposition $[8,39]$. However, a recent study by Holtzman and colleagues [40] has provided new evidence that $\mathrm{A} \beta$ does not directly interact with ApoE to any significant extent. Instead, ApoE competes with $\mathrm{A} \beta$ in an isoform- and concentration-dependent manner for binding to lipoprotein receptor-related protein 1 (LRP1), and this could impact $A \beta$ clearance by glia and across the BBB [40].

\section{Apolipoprotein E facilitates amyloid beta clearance by proteolytic degradation}

The expression of ApoE is transcriptionally regulated by ligand-activated nuclear receptors, which act broadly in 
the brain to regulate lipid metabolism, inflammation, and neuroprotection. The principal type II nuclear receptors regulating ApoE expression are peroxisome proliferatoractivated receptor gamma (PPARY) and liver $\mathrm{X}$ receptors (LXRs) [41], which form an active transcription factor through dimerization with the retinoid $X$ receptors (RXRs). LXR:RXR, upon binding of endogenous oxysterol ligands, promotes the expression of reverse cholesterol transport genes $(A p o E$ and $A B C A 1)$ [21,42]. Astrocytes upregulate ApoE mRNA and protein expression in response to RXR, PPAR $\gamma$, and LXR agonists, leading to the synthesis of ApoE-containing HDL particles [19,43]. There is strong evidence that the isoform of ApoE and its degree of lipidation influence the ability of ApoE to promote $A \beta$ proteolysis both extracellularly and intracellularly and to modulate $\gamma$-secretase activity $[26,44,45]$.

Microglia, which play a prominent role in $A \beta$ degradation, are influenced by ApoE. Terwel and colleagues [46] demonstrated that ApoE secreted in media from primary astrocytes treated with LXR agonists stimulated phagocytosis of $A \beta$ in primary microglia; however, the mechanistic basis of this finding is unknown. This corroborates earlier work from Giunta and colleagues [47], who described increased microglial phagocytosis of aggregated $\mathrm{A} \beta$ with the addition of recombinant ApoE3. The degree of lipidation and ApoE isoform impacts the efficiency of intracellular degradation of $\mathrm{A} \beta$ within microglia, and more highly lipidated ApoE isoforms (E2 > E3 > E4) are most effective [26]. Lee and colleagues [48] recently established that the cholesterol efflux function of ApoE is responsible for accelerating the transport of $A \beta$ to lysosomes in microglia, where it can be degraded by lysosomal proteases.

Many studies in mouse models of AD have demonstrated that treatment with LXR agonists increases levels of $A p o E$ and $A B C A 1$, and this is correlated with cognitive improvements and decreased $A \beta$ deposition $[26,46$, 49-53]. Similarly, PPAR $\gamma$ activation can stimulate the degradation of $A \beta[41,54]$. In addition to its ability to increase ApoE and ABCA1 levels, PPAR $\gamma$ activation has been shown to induce the expression of the scavenger receptor $\mathrm{CD} 36$ on microglia, which increased the uptake of A $\beta$ [55]. LXR agonists and PPAR $\gamma$ agonists have been valuable tools for elucidating the role of $\mathrm{ApoE}$ and mechanism of $A \beta$ clearance in $A D$. Currently, therapeutic potential for LXR agonists has been limited by an unfavorable side-effect profile and inadequate $\mathrm{BBB}$ permeability. Therefore, bexarotene, a BBB-permeable US Food and Drug Administration-approved drug that stimulates both LXR and PPAR $\gamma$ pathways, has been used in AD mouse models. The RXR agonist bexarotene facilitates degradation of soluble $A \beta_{42}$ in a PPAR $\gamma^{-}$, LXR-, and ApoE-dependent manner in both primary microglia and astrocytes [52]. Interestingly, the levels of IDE and neprilysin were unchanged with bexarotene treatment, suggesting that type II nuclear receptor activation may facilitate soluble $A \beta_{42}$ degradation through other mechanisms. In vivo microdialysis revealed that bexarotene reduced the half-life of $A \beta$ in $A P P / P S 1$ and $C 57 \mathrm{Bl} / 6$ wildtype mice but had no effect on $A \beta$ clearance in ApoE-null mice, and this clearly demonstrates that the bexarotene treatment increased $\mathrm{A} \beta$ clearance in an ApoE-dependent manner [52].

\section{Brain to blood and peripheral clearance of amyloid beta}

ApoE and ApoE receptors have also been implicated in the clearance of $A \beta$ across the BBB. Dysfunction of the $B B B$ is seen in both human and animal studies of $A D$ and is linked to poor cerebral blood flow, hypoxia, and accumulation of neurotoxic molecules in the parenchyma (reviewed in [56]). The transport of $A \beta$ across the BBB is of considerable interest because only very small, nonpolar molecules are able to passively diffuse at the BBB. Unlike in peripheral blood-organ interfaces, peptides such as $A \beta$ along with other nutrients and large molecules must be actively transported. Therefore, the equilibrium between $A \beta$ in the plasma and parenchymal ISF can be influenced by the ability of receptors at the $\mathrm{BBB}$ to transport $\mathrm{A} \beta$. The existence of such an equilibrium is the basis of the 'peripheral sink' hypothesis of $\mathrm{AD}$ treatment, which emphasizes clearance of peripheral $A \beta$ species in order to provide a vacuum or 'sink' which favors transport of $A \beta$ out of the brain and into the plasma [57].

Receptor-mediated transport of $A \beta$ from brain to periphery is mediated principally by the ApoE receptor, LRP1, and impairing LRP1 function significantly decreases the clearance of $A \beta$ from the brain $[33,58]$. Conversely, the receptor for advanced end glycation products (RAGE) transports $A \beta$ in the reverse direction and contributes to $A \beta$ accumulation at the BBB and in the parenchyma [59]. LRP1 and RAGE recognize and transport free $A \beta$, but the association of $A \beta$ with ApoE influences receptor transport of $A \beta$. ApoE-bound $A \beta$ is redirected from LRP1 to other LDLR family members, reducing the speed of $A \beta$ clearance at the BBB $[39,60]$. The isoform of ApoE further influences this process, as discussed above.

\section{Conclusions}

Growing evidence from mouse models of $\mathrm{AD}$ and in vivo SILK studies in humans indicates that impaired clearance of $\mathrm{A} \beta$ leads to the development of $\mathrm{AD}$ pathology. ApoE plays an important role in mediating $A \beta$ clearance through multiple mechanisms, as depicted in Figure 1. The expression of ApoE and ABCA1 is regulated by the activation of type II nuclear hormone receptors (LXR, PPAR $\gamma$, and RXR). ApoE is lipidated predominantly by ABCA1. Lipidated ApoE promotes the intracellular 


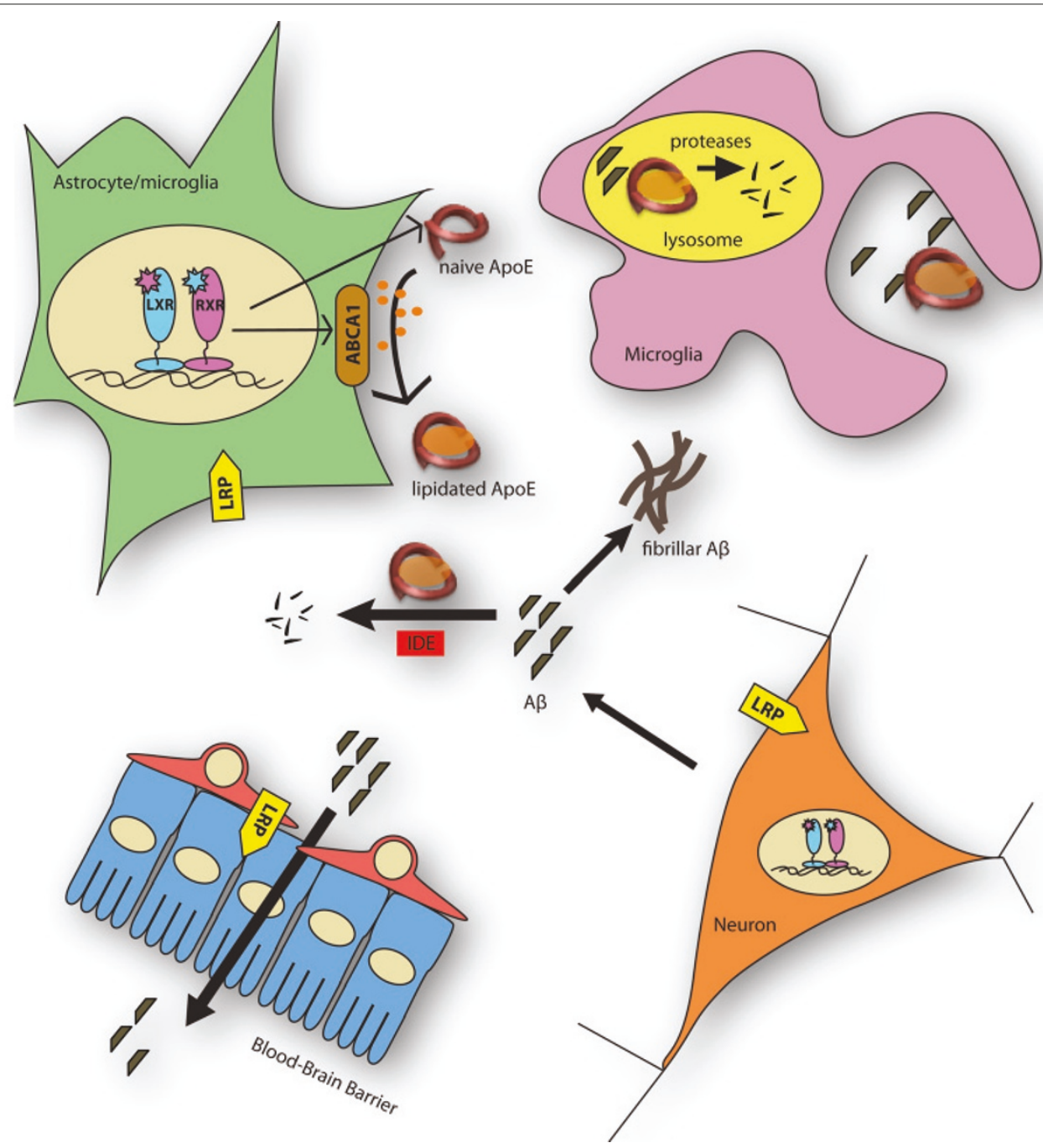

Figure 1. Mechanisms of amyloid beta $(A \beta)$ clearance are mediated by apolipoprotein $E(A p o E)$ and ATP-binding cassette A1 (ABCA1). Activation of nuclear hormone receptors - liver $X$ receptor ( $L X R)$, peroxisome proliferator-activated receptor gamma (PPARY), and retinoid $X$ receptor (RXR) - induces the expression of ApoE and ABCA1. The lipidation of ApoE by ABCA1 stimulates the degradation of $A \beta$ through multiple pathways: extracellular degradation by insulin-degrading enzyme (IDE) or uptake by microglial cells and subsequent lysosomal degradation. A $\beta$ can also be cleared from the central nervous system by binding to ApoE receptors such as low-density lipoprotein receptor (LDLR) or LDLR-related protein 1 (LRP1) that mediate transport across the blood-brain barrier.

degradation of $\mathrm{A} \beta$ by enzymes like neprilysin through its cholesterol efflux function. Extracellular degradation of $A \beta$ by IDE is more efficient in the presence of highly lipidated ApoE. A $\beta$ can also directly bind to ApoE receptors and cross the BBB. ApoE4 is less effective than ApoE3 and ApoE2 at stimulating $A \beta$ clearance, and this may explain, at least in part, why it is such a strong risk factor for AD. Targeting the type II nuclear receptors, such as RXRs, has shown promising therapeutic benefit in mouse models of AD. Treatment with LXR, PPAR $\gamma$, and RXR agonists decreased $A \beta$ pathology and improved cognition in various studies, supporting the hypothesis that increasing the level of lipidated ApoE may be a strong therapeutic strategy for AD.
This article is part of a series on Abeta Catabolism, edited by Elizabeth Eckman. Other articles in this series can be found at http://alzres.com/series/Abeta_catabolism

\section{Abbreviations}

$A \beta$, amyloid beta; ABCA1, ATP-binding cassette A1; AD, Alzheimer's disease; ApoE, apolipoprotein E; APP, amyloid precursor protein; BBB, blood-brain barrier; HDL, high-density lipoprotein; IDE, insulin-degrading enzyme; ISF, interstitial fluid; LOAD, late-onset Alzheimer's disease; LRP1, lipoprotein receptor-related protein $1 ; L X R$, liver $X$ receptor; PPARy, peroxisome proliferator-activated receptor gamma; RAGE, receptor for advanced end glycation products; RXR, retinoid X receptor; SILK, stable isotope-labeling kinetics. 


\section{Competing interests}

KW is an employee of Genentech, Inc. (a member of the Roche group) and receives a fixed salary. GL is an officer of ReXceptor, Inc. (Cleveland, OH, USA). The other authors declare that they have no competing interests.

\section{Acknowledgments}

This work was supported by grants to GL from the National Institutes of Health (AG16740 and AG030482). The funding agenicies played no role in the writing or publication of this review.

\section{Author details}

'Development Sciences, Genentech, Inc., 1 DNA Way, South San Francisco, CA 94080, USA. ${ }^{2}$ Department of Neurosciences, Case Western Reserve University School of Medicine, 10900 Euclid Avenue, Cleveland, OH 44106, USA.

Published: 12 July 2013

\section{References}

1. Ferri CP, Prince M, Brayne C, Brodaty H, Fratiglioni L, Ganguli M, Hall K, Hasegawa K, Hendrie H, Huang Y, Jorm A, Mathers C, Menezes PR, Rimmer E, Scazufca M; Alzheimer's Disease International: Global prevalence of dementia: a Delphi consensus study. Lancet 2005, 366:2112-2117.

2. Selkoe DJ: Clearing the brain's amyloid cobwebs. Neuron 2001, 32:177-180.

3. Cirrito JR, May PC, O'Dell MA, Taylor JW, Parsadanian M, Cramer JW, Audia JE, Nissen JS, Bales KR, Paul SM, DeMattos RB, Holtzman DM: In vivo assessment of brain interstitial fluid with microdialysis reveals plaque-associated changes in amyloid-beta metabolism and half-life. J Neurosci 2003, 23:8844-8853.

4. Castellano JM, Deane R, Gottesdiener AJ, Verghese PB, Stewart FR, West T, Paoletti AC, Kasper TR, DeMattos RB, Zlokovic BV, Holtzman DM: Low-density lipoprotein receptor overexpression enhances the rate of brain-to-blood Abeta clearance in a mouse model of beta-amyloidosis. Proc Natl Acad Sci USA 2012, 109:15502-15507.

5. Miners JS, Barua N, Kehoe PG, Gill S, Love S: Abeta-degrading enzymes: potential for treatment of Alzheimer disease. J Neuropathol Exp Neurol 2011, 70:944-959.

6. Hong S, Quintero-Monzon O, Ostaszewski BL, Podlisny DR, Cavanaugh WT, Yang T, Holtzman DM, Cirrito JR, Selkoe DJ: Dynamic analysis of amyloid beta-protein in behaving mice reveals opposing changes in ISF versus parenchymal Abeta during age-related plaque formation. J Neurosci 2011 , 31:15861-15869.

7. Yan P, Bero AW, Cirrito JR, Xiao Q, Hu X, Wang Y, Gonzales E, Holtzman DM, Lee $J M$ : Characterizing the appearance and growth of amyloid plaques in APP/PS1 mice. J Neurosci 2009, 29:10706-10714.

8. Castellano JM, Kim J, Stewart FR, Jiang H, DeMattos RB, Patterson BW, Fagan AM, Morris JC, Mawuenyega KG, Cruchaga C, Goate AM, Bales KR, Paul SM, Bateman RJ, Holtzman DM: Human apoE isoforms differentially regulate brain amyloid-beta peptide clearance. Sci Trans/ Med 2011, 3:89ra57.

9. Bateman RJ, Munsell LY, Morris JC, Swarm R, Yarasheski KE, Holtzman DM: Human amyloid-beta synthesis and clearance rates as measured in cerebrospinal fluid in vivo. Nat Med 2006, 12:856-861.

10. Mawuenyega KG, Sigurdson W, Ovod V, Munsell L, Kasten T, Morris JC, Yarasheski KE, Bateman RJ: Decreased clearance of CNS beta-amyloid in Alzheimer's disease. Science 2010, 330:1774.

11. Farrer LA, Cupples LA, Haines JL, Hyman B, Kukull WA, Mayeux R, Myers RH, Pericak-Vance MA, Risch N, van Duijn CM: Effects of age, sex, and ethnicity on the association between apolipoprotein E genotype and Alzheimer disease. A meta-analysis. APOE and Alzheimer Disease Meta Analysis Consortium. JAMA 1997, 278:1349-1356.

12. Corder EH, Saunders AM, Risch NJ, Strittmatter WJ, Schmechel DE, Gaskell PC Jr., Rimmler JB, Locke PA, Conneally PM, Schmader KE, et al:: Protective effect of apolipoprotein $\mathrm{E}$ type 2 allele for late onset Alzheimer disease. Nat Genet 1994, 7:180-184.

13. Ashford JW: APOE genotype effects on Alzheimer's disease onset and epidemiology. J Mol Neurosci 2004, 23:157-165.

14. Corder EH, Saunders AM, Strittmatter WJ, Schmechel DE, Gaskell PC, Small GW, Roses AD, Haines JL, Pericak-Vance MA: Gene dose of apolipoprotein E type 4 allele and the risk of Alzheimer's disease in late onset families. Science 1993, 261:921-923.

15. Khachaturian AS, Corcoran CD, Mayer LS, Zandi PP, Breitner JC; Cache County
Study Investigators: Apolipoprotein E epsilon4 count affects age at onset of Alzheimer disease, but not lifetime susceptibility: The Cache County Study. Arch Gen Psychiatry 2004, 61:518-524.

16. Bales KR, Liu F, Wu S, Lin S, Koger D, DeLong C, Hansen JC, Sullivan PM, Paul SM: Human APOE isoform-dependent effects on brain beta-amyloid levels in PDAPP transgenic mice. J Neurosci 2009, 29:6771-6779.

17. Holtzman DM, Bales KR, Tenkova T, Fagan AM, Parsadanian M, Sartorius LJ, Mackey B, Olney J, McKeel D, Wozniak D, Paul SM: Apolipoprotein E isoformdependent amyloid deposition and neuritic degeneration in a mouse model of Alzheimer's disease. Proc Natl Acad Sci U S A 2000, 97:2892-2897.

18. Mann DM, Iwatsubo T, Pickering-Brown SM, Owen F, Saido TC, Perry RH: Preferential deposition of amyloid beta protein (Abeta) in the form Abeta40 in Alzheimer's disease is associated with a gene dosage effect of the apolipoprotein E E4 allele. Neurosci Lett 1997, 221:81-84.

19. Bu G: Apolipoprotein E and its receptors in Alzheimer's disease: pathways, pathogenesis and therapy. Nat Rev Neurosci 2009, 10:333-344.

20. Hirsch-Reinshagen V, Zhou S, Burgess BL, Bernier L, Mclsaac SA, Chan JY, Tansley GH, Cohn JS, Hayden MR, Wellington CL: Deficiency of ABCA1 impairs apolipoprotein E metabolism in brain. J Biol Chem 2004 279:41197-41207.

21. Zelcer N, Khanlou N, Clare R, Jiang Q, Reed-Geaghan EG, Landreth GE, Vinters $\mathrm{HV}$, Tontonoz P: Attenuation of neuroinflammation and Alzheimer's disease pathology by liver x receptors. Proc Natl Acad Sci U S A 2007, 104:10601-10606.

22. Tokuda T, Calero M, Matsubara E, Vidal R, Kumar A, Permanne B, Zlokovic B, Smith JD, Ladu MJ, Rostagno A, Frangione B, Ghiso J: Lipidation of apolipoprotein $\mathrm{E}$ influences its isoform-specific interaction with Alzheimer's amyloid beta peptides. Biochem J 2000, 348 Pt 2:359-365.

23. Wahrle SE, Jiang H, Parsadanian M, Hartman RE, Bales KR, Paul SM, Holtzman DM: Deletion of Abca1 increases Abeta deposition in the PDAPP transgenic mouse model of Alzheimer disease. J Biol Chem 2005, 280:43236-43242.

24. Koldamova R, Staufenbiel M, Lefterov I: Lack of ABCA1 considerably decreases brain ApoE level and increases amyloid deposition in APP23 mice. J Biol Chem 2005, 280:43224-43235.

25. Hirsch-Reinshagen V, Maia LF, Burgess BL, Blain JF, Naus KE, Mclsaac SA, Parkinson PF, Chan JY, Tansley GH, Hayden MR, Poirier J, Van Nostrand W, Wellington $\mathrm{CL}$ : The absence of ABCA1 decreases soluble ApoE levels but does not diminish amyloid deposition in two murine models of Alzheimer disease. J Biol Chem 2005, 280:43243-43256.

26. Jiang Q, Lee CY, Mandrekar S, Wilkinson B, Cramer P, Zelcer N, Mann K, Lamb B, Willson TM, Collins JL, Richardson JC, Smith JD, Comery TA, Riddell D, Holtzman DM, Tontonoz P, Landreth GE: ApoE promotes the proteolytic degradation of Abeta. Neuron 2008, 58:681-693.

27. Michikawa M, Fan QW, Isobe I, Yanagisawa K: Apolipoprotein E exhibits isoform-specific promotion of lipid efflux from astrocytes and neurons in culture. J Neurochem 2000, 74:1008-1016.

28. Hara M, Matsushima T, Satoh H, Iso-o N, Noto H, Togo M, Kimura S, Hashimoto Y, Tsukamoto K: Isoform-dependent cholesterol efflux from macrophages by apolipoprotein $\mathrm{E}$ is modulated by cell surface proteoglycans. Arterioscler Thromb Vasc Biol 2003, 23:269-274.

29. Fitz NF, Cronican AA, Saleem M, Fauq AH, Chapman R, Lefterov I, Koldamova $R:$ Abca1 deficiency affects Alzheimer's disease-like phenotype in human ApoE4 but not in ApoE3-targeted replacement mice. J Neurosci 2012, 32:13125-13136.

30. Strittmatter WJ, Weisgraber KH, Huang DY, Dong LM, Salvesen GS, PericakVance M, Schmechel D, Saunders AM, Goldgaber D, Roses AD: Binding of human apolipoprotein $\mathrm{E}$ to synthetic amyloid beta peptide: isoformspecific effects and implications for late-onset Alzheimer disease. Proc Nat/ Acad Sci U S A 1993, 90:8098-8102.

31. Holtzman DM: Role of apoe/Abeta interactions in the pathogenesis of Alzheimer's disease and cerebral amyloid angiopathy. J Mol Neurosci 2001, 17:147-155.

32. Bales KR, Verina T, Cummins DJ, Du Y, Dodel RC, Saura J, Fishman CE, DeLong CA, Piccardo P, Petegnief V, Ghetti B, Paul SM: Apolipoprotein E is essential for amyloid deposition in the APP(V717F) transgenic mouse model of Alzheimer's disease. Proc Natl Acad Sci U S A 1999, 96:15233-15238.

33. Shibata M, Yamada S, Kumar SR, Calero M, Bading J, Frangione B, Holtzman DM, Miller CA, Strickland DK, Ghiso J, Zlokovic BV: Clearance of Alzheimer's amyloid-ss(1-40) peptide from brain by LDL receptor-related protein-1 at the blood-brain barrier. J Clin Invest 2000, 106:1489-1499. 
34. Namba Y, Tomonaga M, Kawasaki H, Otomo E, Ikeda K: Apolipoprotein E immunoreactivity in cerebral amyloid deposits and neurofibrillary tangles in Alzheimer's disease and kuru plaque amyloid in Creutzfeldt-Jakob disease. Brain Res 1991, 541:163-166.

35. Yang DS, Smith JD, Zhou Z, Gandy SE, Martins RN: Characterization of the binding of amyloid-beta peptide to cell culture-derived native apolipoprotein E2, E3, and E4 isoforms and to isoforms from human plasma. J Neurochem 1997, 68:721-725.

36. LaDu MJ, Falduto MT, Manelli AM, Reardon CA, Getz GS, Frail DE: Isoformspecific binding of apolipoprotein E to beta-amyloid. J Biol Chem 1994, 269:23403-23406

37. Aleshkov S, Abraham CR, Zannis VI: Interaction of nascent ApoE2, ApoE3, and ApoE4 isoforms expressed in mammalian cells with amyloid peptide beta (1-40). Relevance to Alzheimer's disease. Biochemistry 1997, 36:10571-10580.

38. DeMattos RB: Apolipoprotein E dose-dependent modulation of betaamyloid deposition in a transgenic mouse model of Alzheimer's disease. J Mol Neurosci 2004, 23:255-262.

39. Deane R, Sagare A, Hamm K, Parisi M, Lane S, Finn MB, Holtzman DM, Zlokovic BV: apoE isoform-specific disruption of amyloid beta peptide clearance from mouse brain. J Clin Invest 2008, 118:4002-4013.

40. Verghese PB, Castellano JM, Garai K, Wang Y, Jiang H, Shah A, Bu G, Frieden C, Holtzman DM: ApoE influences amyloid-beta (Abeta) clearance despite minimal apoE/Abeta association in physiological conditions. Proc Nat/ Acad SciUSA 2013, 110:E1807-1816.

41. Chawla A, Boisvert WA, Lee CH, Laffitte BA, Barak Y, Joseph SB, Liao D, Nagy L, Edwards PA, Curtiss LK, Evans RM, Tontonoz P: A PPAR gamma-LXR-ABCA1 pathway in macrophages is involved in cholesterol efflux and atherogenesis. Mol Cell 2001, 7:161-171.

42. Morales JR, Ballesteros I, Deniz JM, Hurtado O, Vivancos J, Nombela F, Lizasoain I, Castrillo A, Moro MA: Activation of liver X receptors promotes neuroprotection and reduces brain inflammation in experimental stroke. Circulation 2008, 118:1450-1459.

43. Liang Y, Lin S, Beyer TP, Zhang Y, Wu X, Bales KR, DeMattos RB, May PC, Li SD, Jiang $X C$, Eacho $\mathrm{Pl}$, Cao G, Paul SM: A liver $X$ receptor and retinoid $X$ receptor heterodimer mediates apolipoprotein E expression, secretion and cholesterol homeostasis in astrocytes. J Neurochem 2004, 88:623-634.

44. Donkin JJ, Stukas S, Hirsch-Reinshagen V, Namjoshi D, Wilkinson A, May S, Chan J, Fan J, Collins J, Wellington CL: ATP-binding cassette transporter A1 mediates the beneficial effects of the liver X receptor agonist GW3965 on object recognition memory and amyloid burden in amyloid precursor protein/presenilin 1 mice. J Biol Chem 2010, 285:34144-34154.

45. Osenkowski P, Ye W, Wang R, Wolfe MS, Selkoe DJ: Direct and potent regulation of gamma-secretase by its lipid microenvironment. J Bio/ Chem 2008, 283:22529-22540.

46. Terwel D, Steffensen KR, Verghese PB, Kummer MP, Gustafsson JÅ, Holtzman DM, Heneka MT: Critical role of astroglial apolipoprotein $E$ and liver $X$ receptor-alpha expression for microglial Abeta phagocytosis. J Neurosci 2011, 31:7049-7059.

47. Giunta B, Zhou Y, Hou H, Rrapo E, Fernandez F, Tan J: HIV-1 TAT inhibits microglial phagocytosis of Abeta peptide. Int J Clin Exp Pathol 2008, 1:260-275.
48. Lee CY, Tse W, Smith JD, Landreth GE: Apolipoprotein E promotes betaamyloid trafficking and degradation by modulating microglial cholesterol levels. J Biol Chem 2012, 287:2032-2044.

49. Koldamova RP, Lefterov IM, Staufenbiel M, Wolfe D, Huang S, Glorioso JC, Walter M, Roth MG, Lazo JS: The liver X receptor ligand T0901317 decreases amyloid beta production in vitro and in a mouse model of Alzheimer's disease. J Biol Chem 2005, 280:4079-4088.

50. Riddell DR, Zhou H, Comery TA, Kouranova E, Lo CF, Warwick HK, Ring RH, Kirksey Y, Aschmies S, Xu J, Kubek K, Hirst WD, Gonzales C, Chen Y, Murphy E, Leonard S, Vasylyev D, Oganesian A, Martone RL, Pangalos MN, Reinhart PH, Jacobsen JS: The LXR agonist T0901317 selectively lowers hippocampal Abeta42 and improves memory in the Tg2576 mouse model of Alzheimer's disease. Mol Cell Neurosci 2007, 34:621-628.

51. Fitz NF, Cronican A, Pham T, Fogg A, Fauq AH, Chapman R, Lefterov I, Koldamova R: Liver $\mathrm{X}$ receptor agonist treatment ameliorates amyloid pathology and memory deficits caused by high-fat diet in APP23 mice. J Neurosci 2010, 30:6862-6872

52. Cramer PE, Cirrito JR, Wesson DW, Lee CY, Karlo JC, Zinn AE, Casali BT, Restivo JL, Goebel WD, James MJ, Brunden KR, Wilson DA, Landreth GE: ApoE-directed therapeutics rapidly clear beta-amyloid and reverse deficits in AD mouse models. Science 2012, 335:1503-1506.

53. Kang J, Rivest S: Lipid metabolism and neuroinflammation in Alzheimer's disease: a role for liver X receptors. Endocr Rev 2012, 33:715-746.

54. Heneka MT, Landreth GE: PPARs in the brain. Biochim Biophys Acta 2007, 1771:1031-1045.

55. Yamanaka M, Ishikawa T, Griep A, Axt D, Kummer MP, Heneka MT: PPARgamma/RXRalpha-induced and CD36-mediated microglial amyloidbeta phagocytosis results in cognitive improvement in amyloid precursor protein/presenilin 1 mice. J Neurosci 2012, 32:17321-17331.

56. Zlokovic BV: Neurovascular pathways to neurodegeneration in Alzheimer's disease and other disorders. Nat Rev Neurosci 2011, 12:723-738.

57. Deane R, Bell RD, Sagare A, Zlokovic BV: Clearance of amyloid-beta peptide across the blood-brain barrier: implication for therapies in Alzheimer's disease. CNS Neurol Disord Drug Targets 2009, 8:16-30.

58. Van Uden E, Mallory M, Veinbergs I, Alford M, Rockenstein E, Masliah E: Increased extracellular amyloid deposition and neurodegeneration in human amyloid precursor protein transgenic mice deficient in receptorassociated protein. J Neurosci 2002, 22:9298-9304.

59. Deane R, Du Yan S, Submamaryan RK, LaRue B, Jovanovic S, Hogg E, Welch D, Manness L, Lin C, Yu J, Zhu H, Ghiso J, Frangione B, Stern A, Schmidt AM, Armstrong DL, Arnold B, Liliensiek B, Nawroth P, Hofman F, Kindy M, Stern D, Zlokovic B: RAGE mediates amyloid-beta peptide transport across the blood-brain barrier and accumulation in brain. Nat Med 2003, 9:907-913.

60. Bell RD, Sagare AP, Friedman AE, Bedi GS, Holtzman DM, Deane R, Zlokovic BV: Transport pathways for clearance of human Alzheimer's amyloid betapeptide and apolipoproteins $\mathrm{E}$ and $\mathrm{J}$ in the mouse central nervous system. J Cereb Blood Flow Metab 2007, 27:909-918.

doi:10.1186/alzrt187

Cite this article as: Wildsmith $K R$, et al.: Evidence for impaired amyloid $\beta$ clearance in Alzheimer's disease. Alzheimer's Research \& Therapy 2013, 5:33 